\title{
THE EFFECT OF ENVIRONMENTAL FACTORS TO THE LOCAL GOVERNMENT PUBLIC SERVICES AT THE BORDER REGION
}

\author{
Arifin and Rupita \\ Fakultas Ilmu Sosial dan Ilmu Politik Universitas Tanjungpura \\ E-mail: arifin@fisip.untan.ac.id
}

\begin{abstract}
One of the fundamental problems in the border area of Sanggau Regency is the infrastructure of roads and bridges. Those problems become more complex due to various aspects that affect the governmental institutions are the community, environment, and other aspects. The above problems will produce some implication to many fields such as society, culture, economic, defence and security. The implications are not only local but also national. Based on the problems, the research aims is to describe and analyze the complexity of public basic services for roads and bridges by point of view of the external aspects of an organization. The results of the study show that the main factors in which the public basic services are not optimal are the unfavourable local and socio-economic conditions of the community. The cost needed in basic public services is high enough because of the landscape range. It is exacerbated by the socio-economic constraints of the community which indirectly can hamper the process of running the public services provided. In overcoming of the two problems, the strategic effort that needed is better coordination amongst the organizations in the area. For example, The public works Services (Dinas Pekerjaan Umum) must be coordinated to the other government organization in implementing some programs.
\end{abstract}

Key words: Local Government Organization; Basic Services; Environmental Factors; Border Area

\section{PENGARUH FAKTOR LINGKUNGAN TERHADAP ORGANISASI PEMERINTAH DAERAH DALAM PELAYANAN DASAR PUBLIK DI WILAYAH PERBATASAN KABUPATEN SANGGAU KALIMANTAN BARAT}

\begin{abstract}
ABSTRAK. Salah satu permasalahan mendasar di wilayah perbatasan Kabupaten Sanggau adalah infrastruktur jalan dan jembatan. Permasalahan tersebut menjadi lebih kompleks karena berbagai aspek yang mempengaruhi institusi pemerintahan adalah masyarakat, lingkungan, dan aspek lainnya. Masalah di atas akan menghasilkan beberapa implikasi ke banyak bidang seperti masyarakat, budaya, ekonomi, pertahanan dan keamanan. Implikasinya tidak hanya lokal tetapi juga nasional. Berdasarkan masalah tersebut, penelitian ini bertujuan untuk menggambarkan dan menganalisis kompleksitas layanan dasar publik untuk jalan dan jembatan berdasarkan sudut pandang aspek eksternal suatu organisasi. Hasil penelitian menunjukkan bahwa faktor utama di mana pelayanan dasar publik tidak optimal adalah kondisi lokal dan sosial ekonomi masyarakat yang tidak kondusif. Biaya yang dibutuhkan dalam pelayanan publik dasar cukup tinggi karena rentang lanskap. Hal ini diperparah dengan kendala sosial ekonomi masyarakat yang secara tidak langsung dapat menghambat proses menjalankan pelayanan publik yang diberikan. Dalam mengatasi dua permasalahan tersebut, upaya strategis yang dibutuhkan adalah koordinasi yang lebih baik di antara organisasi-organisasi di daerah. Misalnya, Pelayanan Pekerjaan Umum (Dinas Pekerjaan Umum) harus dikoordinasikan ke organisasi pemerintah lainnya dalam melaksanakan beberapa program.
\end{abstract}

Kata kunci: Pemerintahan Daerah; Pelayanan Dasar; Faktor Lingkungan; Wilayah Perbatasan

\section{INTRODUCTION}

One of the fundamental problems in the border area is the limited basic facilities and infrastructure as well as transportation and telecommunications, which causes the region to have low accessibility and isolated from the surrounding area. This problem requires more serious attention in building the border areas. It is especially in roads and bridges to spur the local growth. This needs to be done because the people of the region play an important and strategic role in maintaining it. In addition, the community will be able to provide many positive opportunities in various fields.

In spurring the local development, the government hasastrategic rolebecause ithas extraordinarystrength if compared to other elements. The government has institutions that are widespread, the authority to make legal authorities, and policies to provide public services, etc. Based on previous research by Usman et al (2016) showed that the internal and external environment of the organization has a positive effect on employee performance on public services, where internal environmental variables consist of indicators: mission, policy, organizational culture, information systems and individual differences of employees, while external environmental variables consisting of indicators: labor force, law/legislation, society, technology, and economy.

By the implementation of the local autonomy policy as an embodiment of the principle of decentralization, there has been hoping for people 
who lived in many districts including border areas. The step taken in responding to this autonomous opportunity is a policy of structuring local organizations, which will operationally provide services to the community which in turn will be able to further spur local development. In addition, the policy for structuring local organizations is motivated by problems that are relevant to the changes in local government organizations.

Policy for structuring the local organization of government before the implementation of PP N0. 41 of 2007, was guided by Government Regulation (PP) Number 8 of 2003 which in its implementation gave enormous power and freedom to the Local Government. The policy on structuring the local organization of government based on the guidelines for implementing Government Regulation Number 8 of 2003 places more emphasis on rightsizing efforts, namely efforts to simplify local organizations of government, more professional, flat, transparent, short hierarchies and de-neutralize their authority. Organizations of a local organization are prepared based on clear vision and mission. The pattern of organizational structure is arranged based on real needs and follows the strategy to achieve the organization's vision and mission that has been set before. In the instructions for implementing the Government Regulation, a concrete "mandatory authority" approach is based on the urgency of the formation of local organizations to approach the rationally objective needs.

The policy is considered as a strong control to the Local Government because the central government stipulates the "mandatory authority". This greatly limits the demands of the local government which are only 3 (three) services of local government organizations. The establishment of local technical institutions psychologically places less important institutional positions. This will directly or indirectly affect its performance in providing services and responding to the demands of an increasingly complex society.

One government organization that is obliged to overcome the problem of low accessibility of border areas is the Public Works service (Dinas Pekerjaan Umum). It serves the community to provide road and bridge that serve as an opening for local isolation, a connecting one region to another, and a linking between physical facilities and infrastructure from one area to another.

In previous studies on Indonesia's cooperation relationship with Malaysia mentions that Indonesia and Malaysia have almost the same historical ties (serumpun), so that the border communities in
Malaysia with border communities in Indonesia have almost the same culture so that it has good prospects in building inter-cultural and economic cooperation (Asmarani, et al., 2014; Yovinus, 2016; Utomo, 2017).

The Public Works Services in carrying out the public services found various constraints. The external constraints of the organization are both the environmental aspects of the organization and the people who received the services. As stated by Saefullah (2017), to provide better public services needs an effort to understand the attitudes and changes in their public interests. Changes in the life of the world are so fast that it has a rapid influence on changes in attitudes and behaviour of society. Public organizations such as the institutional instruments of the Sanggau Regency area were formed in essence to provide services to the community. In reality, not all the local government organizations provide their duties properly in implementing the basic services that are the community's rights. For this reason, there must be various efforts in carrying out by the local apparatus of the local organization in order that the basic services can be carried out optimally.

Regarding the service concept as the government's obligation to provide services to the community, Rasyid (2010) explains that:

"Viewed by the side of the government, the public service is a process of fulfilling the community's needs regarding basic rights and granting rights whose forms can be in the form of services. For the government, The service issues are becoming increasingly interesting to be discussed because they involve one of the three essential functions of the government. Concerning this, the public service emphasizes on prioritizing the public interest, facilitating the public affairs and shortening the process of implementing public affairs."

The development efforts in order to penetrate local isolation require a maximum role from the Public Works Services in the area. Success in achieving that effort does not only depend on the internal side of the organization but also requires any cooperation from the external organization so the desired achievements in good public service can be achieved well.

An organization that developed well will not be separated from various elements that exist in the environment itself such as various physical sources, conditions, climate, regulations or laws, social, cultural, and other conditions that will certainly affect the local organization. In one hand, the existing environment can be an opportunity for 
the organization to be able to take the advantages of these environmental conditions in developing the organization in a better direction. Thus local organizations, especially the Public Works Services, can take the advantage of the various opportunities that exist in the border areas.

The utilization of this opportunity can be a function in accelerating the achievement of the organization's goals which is especially in serving the people on the border.

Hicks (1972) describes the interdependence between organizations and their environment described as the following figure;

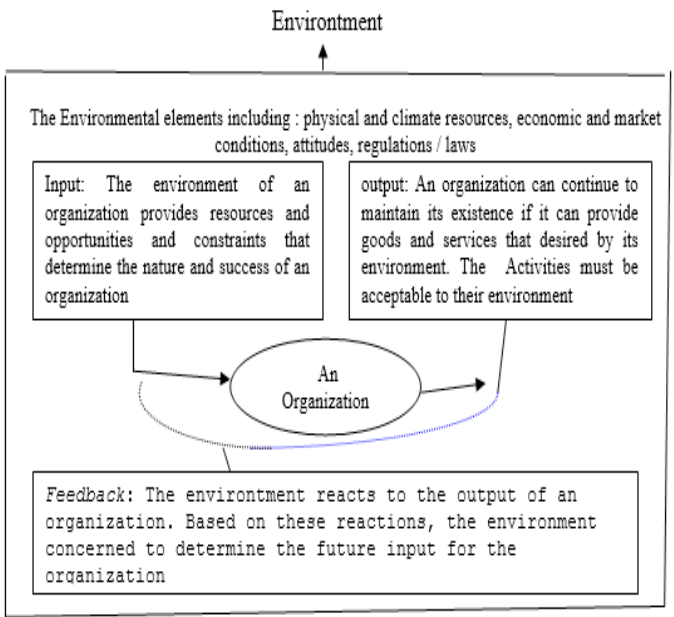

(Hicks, 1972)

Figure 1. Environtment and its surrounding

From the above picture can be seen that the organization and environment are interdependent. Organizations depend on their environment to reach the resources and opportunities needed for their existence.

In general, this study aims to find facts that will be described and analyzed to explain how the external aspects of an organization are influenced.

Moving on from the research aims, the research problems are formulated as follows: "How are The Environmental factors affect to the local government organization?"

\section{METHOD}

The research method used is qualitative design. The researcher goes directly to the research field in collecting data through government organizations, communities, and other data sources. It is described as it is.

In this study, the data collection techniques that researchers conducted are by observation, interviews, documentation and triangulation. In qualitative analysis, researchers try to focus on showing the meaning, description, clarification and placement of data in their respective contexts, and more in terms of words than numbers.

Thus, in this analysis, the researcher carries out the process of compiling and classifying data in categorization, conceptualization and contextualization and interpretation to obtain meaning and conclude the results of the study.

In the process of analyzing qualitative data, the researcher carries out the stages of data reduction with the stages of compiling data in units, categorizing units, carrying out checks on the validity of data which then proceed to the next stages.

The last step is to test the validity and reliability of the data. Tests carried out by several methods of testing such as credibility, transferability, dependability, reliability, and confirmability.

\section{RESULTS AND DISCUSSION}

Based on geographical conditions, there are many hindrances encountered by Sanggau Regency. The condition that bordered on more prosperous neighbouring countries with adequate facilities and infrastructure is a separate obstacle for Sanggau District. It is especially related to the flow of human resources and natural resources to the neighbouring country. Besides, Sanggau Regency which is generally a hilly and swampy highland area is flowed by 5 rivers, namely the Kapuas River, Sekayam River, Mengkiang River, Kambing River, and Tayan River. By the geographical conditions, It is caused that the span of control for local organizational will find natural obstacles that create the difficulties to reach in serving the community of the area.

Areas that are adjacent to urban areas will find it easier to get service coverage from local organizational. By this condition, many villages in the border areas, such as Suruh Tembawang which is a village in Entikong sub-district, Bungkan village, and Malenggang village in Sekayam sub-district do not feel adequate transportation facilities and infrastructure services.

Another problem arising from natural barriers in Sanggau District is that the villages in the border area do not receive adequate attention from the local government and the central government. Because of the lack of government attention, many social problems are difficult to solve by the government itself. In the other hand, Indonesian government's dependence on foreign loans is proof that the international monetary environment is strong in influencing government bureaucratic policies at the local level (Nurasa, 2013).

In addition to the above findings, field research shows that there are two external aspects of the 
organization which are the main obstacles in public services are namely the physical condition of the area and the socio-economic conditions of the community. Employee performance on the public services can be seen from three variables, namely work discipline, organizational culture and work environment, where the three affect each other (Primananda \& Djastuti, 2015).

\section{The Situation of the Border Area in Sanggau District}

Based on the span of control and transportation in Entikong and Sekayam Subdistricts, there are several categories of local conditions. Areas that have easily in transportation because of roads that connected well amongst the area are only 6 villages. The others are some rural areas with remote terrain conditions and transportation. These are difficult to be accessed due to unfavourable road conditions totalling 14 villages (BPS Kabupaten Sanggau, 2019).

Entikong border area in the era of Jokowi's government, changed the paradigm of development from what was once a border area seen as a backyard of the country, to a border area as the home of the country or the vanguard of the country. Then, the government built the Border Development Centre (BDC) area, in order to accelerate development at the Entikong border.

The development of BDC area is intended as a center of industrial activities, services and trade, as well as an integrated and independent training and labor service center managed by a professional institution equipped with adequate facilities and infrastructure (Laporan Pemerintah Kecamatan Entikong, 2010). Meanwhile, the multidimensional poverty situation in Entikong is still relatively large in remote village areas (Niko, 2020). This is not only the case in Entikong region, but the border area in West Kalimantan in general (Niko, 2020; Rupita, 2020).

By observing the condition, it is clear that there are still so many villages that have not been properly touched by road and bridge facilities and infrastructure. In general, the geographical conditions of Sanggau Regency in Entikong and in Sekayam sub-districts which are hilly area and have many rivers flowed. The solution to the problems is river transportation. Based on field observations, there is absolutely no government that provides traffic facilities and infrastructure through this river route. Traffic with this river lane is more independently managed by the local community in order to overcome the remoteness of the sub-district areas which are far from the cities of the sub-district.
Entikong Border has complete security forces such as police, immigration security posts, and customs. However, violations of cross-border smuggling trade will not only widen the economy but human security will also be threatened (Kristi, et al., 2018). This means that serious threats then concern the security of people (communities) in the border areas of the country. This requires a comprehensive diplomatic settlement.

Diplomacy relates to the management of relations between state and non-state actors. Border diplomacy is the implementation of foreign policy in order to set limits on 3 matra (land, sea and air) and the management of border areas as well as international cooperation to maintain the Republic of Indonesia on the basis of the principles of foreign policy of the Republic of Indonesia and applicable international law (Iva and Fauzan, 2012).

The remoteness condition in the above mention is an area with terrain with a range of more than a few kilometres from the subdistrict city and with inadequate means of transportation and transportation. By watching at its vast and remote geographical conditions, it will be a challenge for the local organization of Sanggau District to provide effective and fair public services that can touch all levels of society. This cannot be achieved if public services are only carried out by the District Public Works Services without intensive cooperation with both the Provincial Public Works services and the central Public Works services. In addition, restructuring the organization of the Public Works Services is needed to be directed at the establishment of service operational units at the sub-district and village levels with the implemented programs and completed facilities and infrastructure services that are in accordance with standards and with decentralized decision-making patterns.

The establishment of a service operational unit with the complete facilities and infrastructure in accordance with service standards is one of the requirements to bring service facilities closer to the people who need them and increase the role of the local organization in increasing the effectiveness of the services provided.

An organization must adapt to the environment in order to be able to provide effective services to the surrounding community. Pfeffer (1982) stated that a good and effectively functioning organization is an organization that can provide benefits to society. From this statement, it is clear that an organization must be able to see what is needed by its environment and how the organization can adapt to its environment. Moreover, the government organizations, especially 
the Sanggau District Public Works Services, face a specific environment in the border area when compared to other local conditions.

Specific conditions for Sanggau District in general, and especially for the two Sub-districts in this study are seen in the broadly geographical physical condition and the social conditions of the undeveloped people that coupled with various social problems in it. Such physical conditions result in certain areas that are difficult to reach by transportation so that many villages are still traditional and in a relatively low socio-economic and cultural level environment. The condition of the physical environment of remote and difficult to reach areas is a demand for the government to be able to reach these areas by optimizing the role of government organizations.

In connection with the above geographical conditions, there are several other environmental conditions that need to be considered in performing services. First, the types of land which are mostly less dense types are almost evenly distributed in all districts. Second, the rainfall is quite high, with the highest and lowest rainfall days with a range of 39 days to 122 days (BPS Kabupaten Sanggau, 2019). Third, hilly natural conditions lead to ease in erosion due to the high flow of water.

Entikong Border has also been built international goods terminal facility that becomes the central trade of import exports. Aspects of the benefits of the International Goods Terminal (TBI) are still not seen reaching the local community, it is seen that there is still a selection of local products that are worthy of export products (Niko \& Samkamaria, 2019).

The existence of international terminals will increase the number of illegal cases at the border. Niko (2017) mentioned that there are cases of human trafficking, especially the victims are women at the border of the country. The occurrence of illegal trade in the border areas of the country, such as people trafficking, drug trafficking and illegal weaponry occurring at the border is an organized crime and weak human security at the borders of the country (Elyta, 2012; Niko \& Tasmal, 2020).

\section{The Socio-Economic Community}

The Population problems and social conditions in Sanggau Regency are separate obstacles for local government in serving its communities. One of them is the low level of resources. It can be seen how the Sanggau District Local Development Index is still low. This condition is exacerbated by the condition of both educational facilities and infrastructure and inadequate health. From the collected data, it can be seen that the imbalance amongst the number of schools, the number of students and the number of teachers. This is the same as health facilities and infrastructure. The existence of health facilities and infrastructure between one sub-district and the other is felt to be unbalanced. For example, there is one sub-district that does not have a Puskesmas (Health Unit) at all, while the other sub-districts already have enough Puskesmas. Moreover, existing medical personnel is not adequate.

The development of border areas is also directed to improve the welfare of people in border areas, which due to their remote location and far from the centers of economic growth, are currently still in a state of backwardness. Improving the welfare of local communities is also very important to be reviewed in terms of national resilience. The concept of resposibility to protect by a government that then adopts the concept of sovereignty in full, has limitations in relation to the concept of humanity and the capacity to act effectively to protect its citizens from threats to their security both from abroad and from within the country (Chandler, 2009).

This low resource condition in service practices carried out by local officials will face its own obstacles. The community especially can see environmental conditions that can provide more benefits. For example, based on interviews conducted by Public Works Services officials commenting that It is sometimes that local people protest against the facilities construction and infrastructure. They protest it because they did not see a profit factor in the future, which would be a pioneer for a local facility as a whole. Weakness in seeing the real condition of an environment is due to the low level of education of the community. It is sometimes a limiting factor found in the local field in serving the community.

By observing the composition of the population whose average line of business is agriculture and plantation, the constraints faced by the local officials, especially the Public Works Services, are the conditions of roads and bridges that have been built will be more quickly damaged due to the very heavy distribution of goods and services. This condition is further exacerbated by the condition of the area that is often rained so it affects the physical nature of the roads that have been built which will be easily damaged. This condition will be easily seen if the journey is carried out in border areas which are the centres for producing palm oil and other agricultural products.

In addition to the above geographical physical constraints, It has a large area but it has not been maximally managed by the local government. The 
condition of agricultural land in Sekayam Subdistrict, which is larger than the area of Entikong Subdistrict, has experienced the same condition. The paddy field is still not utilized optimally by the community. There are still many agricultural lands as sleeping land that is overgrown by plants that have no economic value. According to information from the agriculture instructor, they said that the land is owned by other residents who live in other towns whose aims are only to invest. As a result, the land cannot be used by someone or a group of people if they do not get permission from the landowner. Another reason is that the vacant land is owned by the adat community. In other words, the land belongs to the adat whose utilization is surrendered by the people through the applicable local customary law.

Another problem is that the vacant land that is still large in numbers is unclear. The land is owned by the government or the property of residents who are not domiciled in the area. It is clear that the land in the border area is large in numbers, but there are still many specific obstacles that cause new obstacles for the government to implement a program. The program which is still an obstacle for local governments to implement is that there is no agreement between citizens and the government in managing land in the border area which will be used as a safety belt. The government's plan will establish plantations along the border area so that it will indirectly mark Indonesia's boundary areas and will have an economic effect on the community. This is difficult geographical problems and land ownership becomes a separate obstacle for the government.

Another problem related to the border community resources is a lack of guidance in trading and cultivating so that trade patterns and cultivation of land are not as expected. According to other information obtained from sub-district staff in the fields of economy and development, the other constraints in the plantation sector are community plantation patterns that have not yet been clearly formed so that it is one of the factors the disadvantages to the farmers themselves. For example, plantations that are very rapidly developing and their marketing are prospect full are coconuts. The local community will immediately plant the coconut in accordance with the current trends and profitable market prospects. The irony is that even though they have lime gardening or other plantation commodities that they have harvested for several years they are willing to replace the existing plantations with the plantation that commodities are marketable.

Furthermore, some forms of violations in border areas include trafficking (human, weapons, drugs), illegal logging, and illegal fishing. Furthermore, Regulation of the Minister of Defense of the Republic of Indonesia Number 57 of 2014 on strategic guidelines for military defense categorizes human trafficking as one of the threats with economic value (Elfitriani, et al, 2018).

The above conditions are certainly very detrimental to farmers, but they prefer to speculate in the field of plantations in improving a better standard of living. This condition will certainly be a separate obstacle for an institution of local government, especially institutions that handle that field.

Related to the above problems, It cannot blame one side or just one field. The above problems are caused by various factors that influence one each other. One of the factors that can be said to be dominant in this problem is the existing of roads and bridges infrastructure in the area is not adequate enough so that it affects lack of supports in the flow of goods and services itself. With the limitations of roads and bridges infrastructure, this will have other negative consequences. The consequences are difficult to penetrate in marketing plantation and agricultural products in Sanggau District, especially in Entikong sub-district, which is the first border buffer zone. As a result, Planters and farmers usually market their plantation products to neighbouring countries. They market their commodities in the neighbouring area due to the closed range and adequate infrastructure.

In addition to the above conditions, The selling price obtained from neighbouring countries is greater than the local selling price. Raw materials sold by the local people of the border areas are processed by the neighbouring country to be the products that are ready to use. This can be seen from the processed products from neighbouring countries on the market. Besides, the neighbouring country buys raw materials from plantation and agriculture in the border area with the intention that it will export them to European countries at a higher price. Thus, The impact caused by the inadequate infrastructure can have a broad impact on the local economy.

Another obstacle that is felt to be very necessary and significant aspects in influencing the socio-economic conditions of the community is the condition of roads and bridges. Based on existing data, the phenomenon seen is maintenance and additional roads per year for national roads and provincial roads, which have remained relatively unchanged. While the addition of district roads and village roads always go up with a significant increased. This is possible because the responsibilities and authority carried out by the district are greater than the central and provincial governments. 
To accelerate the infrastructure growth is expected that the cooperation of the three parties. So, It is not necessary to blame each other and give the responsibility up in the building and managing the roads to the government of Sanggau Regency. In addition to the department that handles in building the infrastructure, the Public Works services also need cooperation with other people such as in the education sector. It is hoped that roads and bridges that are built will function optimally in connecting one school to the other schools or one facility to other facilities. Based on this, it is clear that the handling of road cases by related parties needs to be synergized with each other. With the synergy between the public work services and other institutions, the basic services problems of roads and bridge facilities and infrastructure will be able to be reduced.

\section{CONCLUSION}

The environmental factors to the local government organization which are the main obstacles in the basic services of road and bridge facilities are the range of nature, climate, and the isolation of the area. This condition requires high costs and extra cooperation between institutions in overcoming the problems. Apart from the condition of the area, the socio-economic conditions of the community are also very influential. This can be seen in the uneven distribution of the population, the mental attitude of the unsupportive community in building infrastructure, the orientation of the economic activities of the people that oriented to neighbouring countries.

Because the Sanggau District Public Works Office is in a border area with complex problems, it is better to resolve the problems by intensive, synergic and continuous collaboration with other local government organizations in the area. In carrying out programs, projects or other activities of the Public Works services, they should discuss it to other government organizations that are related to these activities that the activities can reduce adverse impacts on the community and to be more effective in serving the community.

\section{ACKNOWLEDGMENTS}

Authors would like to thank the Dean of the Faculty of Social and Political Sciences Universitas Tanjungpora Pontianak, for the support given to the author to conduct this research. The author also thanks all informants as well as various parties who contributed, either directly or indirectly, to the writing of this manuscript.

\section{REFERENCES}

Anonim. (2010). Laporan Pemerintahan Kecamatan Entikong. Sanggau: Pemerintah Kecamatan Entikong.

Asmarani, M., dkk. (2014). Kerjasama Sosial dan Ekonomi Malaysia-Indonesia. Jurnal Tesis PMIS-Untan-PSIP, 1-16.

BPS Kabupaten Sanggau. (2019). Kecamatan Entikong dalam Angka 2020. Sanggau: Badan Pusat Statistik Kabupaten Sanggau.

Chandler, D. (2009). Unravelling The Paradox of the "Responsibility of Protect". Irish Studies in International Affairs, 20, 27-39.

Elfitriani, Y., Dkk. (2018). Indonesia Defense Diplomacy In Supporting To Eliminate Human Trafficking In Indonesia-Malaysia Border. Jurnal Diplomasi Pertahanan. 4(3), 120-136.

Elyta. (2012). Penanggulangan Perdagangan Perempuan di Perbatasan Entikong Kabupaten Sanggau Kalimantan Barat: Perspektif Keamanan Manusia. Indonesian Journal of Dialectics. 2(2), 1-16.

Hicks, H. G. (1972). Management of Organizations: A System and Human Resources Approach. New York: MsGraw-Hill Education.

Iva, R., dan Fauzan. (2012). Problem Diplomasi Perbatasan dalam Tata Kelola Perbatasan Indonesia-Malaysia. JSP, 16(2), 56-63

Kristi, P. (2018). Border Diplomacy Pemerintah Republik Indonesia Dalam Menangani Penyelundupan Gula Di Entikong. Jurnal Transformasi. 1(34), 1-12

Niko, N. (2017). Fenomena Trafficking in Person di Wilayah Perbatasan Kalimantan Barat. RAHEEMA: Jurnal Studi Gender dan Anak. 4(1), 32-37.

Niko, N. (2020). Strategi pemberdayaan berbasis vocational skill pada perempuan miskin di perbatasan entikong (IndonesiaMalaysia). YINYANG: Jurnal Studi Islam, Gender dan Anak. 15(1), 1-17.

Niko, N., \& Samkamaria. (2019). Terminal Barang Internasional (TBI) dalam Konteks Pembangunan Ekonomi Masyarakat di Perbatasan Entikong, Indonesia-Malaysia. Indonesian Journal of Religion and Society. 1(2), 104-114. 
Niko, N., \& Tasmal, D. T. (2020). The Phenomenon of Drugs Trafficking in the Border Region Indonesia-Malaysia Jagoi Babang, West Kalimantan. Jurnal Sosiologi Nusantara. 6(1), 1-12.

Nurasa, H. (2013). Analisis Organisasi Pemerintah Daerah Khusus Ibukota Jakarta Sebagai Sebuah Sistem Terbuka. Sosiohumaniora. 15(1), 80-90.

Pfeffer, J. (1982). Organization Theory. Pitmall publishing.

Pramudietha, G. (2017). Analisis Budaya Organisasi Pemerintah Daerah (Pemda) di Era Otonomi Daerah. Komuniti. IX(1), 63-77.

Primananda, N. \& Djastuti, I. (2015). Pengaruh Disiplin Kerja, Budaya Organisasi dan Lingkungan Kerja Terhadap Kinerja Pegawai Sekretariat Daerah Pekalongan. Diponegoro Journal of Management. 4(1):1-11.

Rasyid, R. (2010). Desentralisasi dalam menunjang pembangunan Daerah dalam Pembangunan Administrasi di Indonesia. Jakarta: PT Pustaka LP3ES.
Rupita. (2020). Kehidupan Perempuan Perbatasan: Kemiskinan dan Eksploitasi (Kajian Kasus Perbatasan Jagoi Indonesia-Malaysia Kalimantan Barat). Ganaya: Jurnal Ilmu Sosial dan Humaniora. 3(1), 135-145.

Saefullah, H.A.D. (2017). Pemikiran Kontemporer Administrasi Publik Perspektif Manajemen Sumber Daya Manusia dalam Era Desentralisasi. Bandung: AIPI dan PK2W Lemlit Unpad.

Usman, C., Liando, D. M. \& Rumawas, W. (2016). Pengaruh Lingkungan Internal dan Eksternal Organisasi Terhadap Kinerja Pegawai (Studi pada Pegawai di Kantor Otoritas Bandar Udara Wilayah VIII Manado). Society: Jurnal Ilmu Sosial dan Pengelolaan Sumber Daya Pembangunan. Edisi XXI:19-33.

Utomo, A.P. (2016). Strategi Pengembangan Industri Kreatif Indonesia dalam Menghadapi Masyarakat Ekonomi ASEAN. Jurnal Ilmu Hubungan Internasional. 5(4), 1.365-1.380.

Yovinus. (2016). Prospek Kerjasama Bilateral Indonesia-Malaysia Bagi Kesejahteraan Masyarakat di Wilayah Perbatasan. Jurnal Dinamika Global. 1(2), 24-43. 